\title{
Correction to: Clinical and Molecular Delineation of Cutis Laxa Syndromes: Paradigms for Elastic Fiber Homeostasis
}

Aude Beyens, Lore Pottie, Patrick Sips, and Bert Callewaert

\section{Correction to:}

\section{Chapter 13 in: J. Halper (ed.), Progress in Heritable Soft Connective} Tissue Diseases, Advances in Experimental Medicine and Biology 1348, https://doi.org/10.1007/978-3-030-80614-9_13

The book was inadvertently published with incorrect Chapter title. The title has been corrected in Chapter 13 now. 